\title{
Identification of a New Potyvirus Associated with Chlorotic Vein Banding Disease of Spathiphyllum spp., in Andhra Pradesh, India
}

\author{
M. Padmavathi', K. P. Srinivas ${ }^{1}$, Ch. V. Subba Reddy', B. Ramesh ${ }^{1}$, K. Navodayam ${ }^{2}$, J. Krishnaprasadji ${ }^{2}$, \\ P. Ratan Babu' ${ }^{2}$ and P. Sreenivasulu* ${ }^{1 *}$ \\ ${ }^{1}$ Department of Virology, College of Sciences, Sri Venkateswara University, Tirupati-517 502, Andhra Pradesh, India \\ ${ }^{2}$ Horticultural Research Station, Andhra Pradesh Horticultural University, Kovvur-534 350, West Godavari district, Andhra \\ Pradesh, India
}

(Received on June 16, 2010; Accepted on November 10, 2010)

\begin{abstract}
The genome of a potyvirus isolate associated with chlorotic spots and vein banding symptoms on Spathiphyllum spp., in Andhra Pradesh state, India was amplified by RT-PCR using degenerate potyvirus primers, amplicons cloned, and sequence $(1.6 \mathrm{~kb})$ analyzed. This virus isolate shared maximum identity of $74.8 \%$ and $80.2 \%$ at coat protein (CP) gene nucleotide (906 nucleotides) and amino acid (302 amino acids) levels, respectively with Dasheen mosaic virus (DsMV)-M13 isolate reported from China. But its 3'-UTR (258 nucleotides) had maximum identity of $62.5 \%$ with DsMV-Vietnam isolate. The deduced molecular weight of $C P$ is $33.57 \mathrm{kDa}$ and it contained DAG triplet in its Nterminal region. In CP amino acid based phylogenetic analysis, this virus isolate represented a separate branch but closer to DsMV isolates cluster. Based on the molecular criteria set for the discrimination of species and genus in the Potyviridae family, the present virus isolate was identified as a distinct virus species in the genus Potyvirus and proposed the name Spathiphyllum chlorotic vein banding virus (SCVbV).
\end{abstract}

Keywords : genome sequence analysis, potyvirus, Spathiphyllum spp.

Aroids found naturally in different habitats in tropical and subtropical regions of the world. They are cultivated through vegetative propagules (corms, cormels, tubers, stem pieces) and or by micropropagation as food crops, foliage or flowering ornamentals, aquarium, and medicinal plants. Spathiphyllum spp. (Peace lily) are commonly cultivated as foliage ornamentals.

Eight viruses (Bean yellow mosaic virus, BYMV; Calla lily latent virus, CLLV; Dasheen mosaic virus, DsMV; Konjac mosaic virus, KoMV; Peace lily mosaic virus,

\footnotetext{
*Corresponding author.

Phone) +91-9849102267, FAX) +82-

E-mail) pothursree@yahoo.com
}

PeLMV; Soybean mosaic virus, SMV; Turnip mosaic virus, TuMV; and Zantedeschia mild mosaic virus, ZaMMV) that belong to the genus Potyvirus, family Potyviridae have been reported to naturally infect different aroids world wide (Chen et al., 2003; Chen et al., 2006; Huang and Chang, 2005; Kwon et al., 2002; Nishiguchi, 2006; Pham et al., 2002; Shi et al., 2005; Zettler et al., 1978; GenBank A/C DQ851494). Among these potyviruses, DsMV is world wide in distribution and naturally infects several aroid and orchid plant species (Farrcyrol et al., 2006; Zettler et al., 1978). Many of the above potyviruses have been reported to induce chlorotic spotting, chlorotic ring spotting, chlorotic vein banding, chlorotic feathery vein mottling, mosaic, leaf distortion/malformation, and reduction in the vigor of growth of aroid plants. Further, they decreased the rooting of virus contaminated aroid propagules.

In India, the virus infecting aroid plants, presumed to be DsMV based on external symptoms for a long period, was later confirmed (Ahlawat et al., 2003; Pandit et al., 2001; Ram et al., 2003; GenBank accession number FJ160764). In addition to DsMV, a carla-like virus has been suspected to infect Amorphophallus paenifolia (Elephant foot yam) in Assam, India (Ahlawat et al., 2003). Very recently, the virus isolates associated with natural infections of Colocasia esculenta, Caladium, and Dieffenbachia spp., in Andhra Pradesh state, India were found to be KoMV (Padmavathi et al., 2010). Aroid foliage ornamentals are common in indoor and outdoor gardens and nurseries in Andhra Pradesh state. Symptoms characteristic of virus infections have been noticed on Spathipyllum spp., plants. The initial studies have revealed the association of a potyvirus isolate with such infections (data not shown). To confirm this, the total RNA isolated from Spathiphyllum spp., showing chlorotic spotting and vein banding was amplified by RTPCR using degenerate potyvirus primers (Gibbs and McKenzie, 1997), amplicons were cloned, and sequence analyzed to determine the correct identity of the virus. 


\section{Materials and Methods}

Virus sources and maintenance. The ornamental plant nurseries around Rajahmundry, (East Godavari district) and in and around Tirupati, Chittoor district, Andhra Pradesh state were surveyed to record the occurrence of virus infections on aroid ornamentals. The leaves and vegetative propagules of six representative symptomatic (Fig. 1A) and asymptomatic Spathiphyllum spp., samples were collected for screening by direct antigen coating-enzyme linked immunosorbent assay (DAC-ELISA) (Clark and Bar-Joseph, 1984) using Peanut green mosaic potyvirus antiserum (Dr. P. Sreenivasulu, corresponding author). The ELISA-positive $\left(\mathrm{A}_{405}\right.$ values ranged from 0.19 to 0.45$)$ and negative samples were propagated through vegetative propagules in the wire mesh house of the Department of Virology for further analysis.

Isolation of total RNA, RT-PCR, and cloning. The total RNA was extracted from ELISA-positive Spathiphyllum spp. as well as from ELISA-negative samples using Trizol reagent (Gibco BRL, UK) according to the manufacturer's protocol and the isolated RNA was resuspended in $20 \mu \mathrm{l}$ of RNase-free water. $5 \mu$ of RNA was initially denatured at $55-60^{\circ} \mathrm{C}$ for $10 \mathrm{~min}$ and set for first strand cDNA synthesis involving oligo $\mathrm{d}(\mathrm{T})_{17}$ primer (Promega, Madison, Wisconsin, USA) and M-MuLV-RT (Fermentas, Burlington, Ontario, Canada) according to the manufacturer's protocol. The second strand synthesis was performed by taking $1.0 \mu \mathrm{l}$ of cDNA in a $25 \mu 1$ reaction mixture involving $2.5 \mu 1$ of 10 X PCR buffer, $25 \mathrm{mM} \mathrm{MgCl}_{2}, 0.5 \mu \mathrm{l}$ of $10 \mathrm{mM}$ dNTP mix, $1 \mathrm{U}$ of Taq DNA polymerase (Fermentas), and 20 pmol of the degenerate potyvirus primers, i.e., potyvirid primer 1: 5'-CACGGATCCCGGG (T) $)_{17}$ (AGC)-3' and potyvirid primer2: 5'-ACCACAGGATCCGG(TCG)AA(CT)AA(CT) AGCGG(GTA)CA(AG)CC-3' as reported by Gibbs and
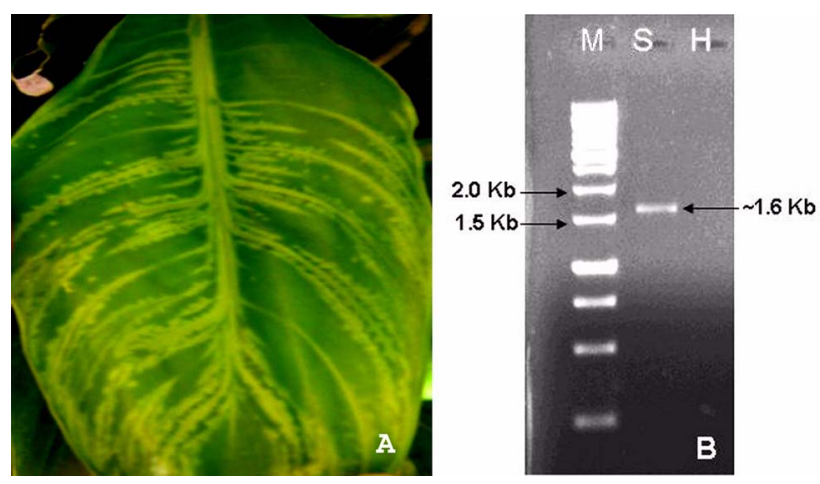

Fig. 1. (A) Chlorotic vein banding symptoms on Spathiphyllum spp., leaf. (B) RT-PCR amplicons resolved by $1 \%$ agarose gel electrophoresis. M: $1 \mathrm{~Kb}$ DNA marker, S: Infected Spathiphyllum spp., H: Healthy Spathiphyllum spp.
McKenzie (1997). The above PCR reaction was subjected to initial denaturation of $94^{\circ} \mathrm{C}$ for $5 \mathrm{~min}$, followed by 35 cycles of $94^{\circ} \mathrm{C}$ for $30 \mathrm{sec}, 55^{\circ} \mathrm{C}$ for $1 \mathrm{~min}$, and $72^{\circ} \mathrm{C}$ for 2 min and final extension of $72^{\circ} \mathrm{C}$ for $10 \mathrm{~min}$.

The amplified products were electrophoresed along with $1 \mathrm{~Kb}$ DNA ladder (Fermentas) on 1\% agarose gel and the amplified products were gel extracted using the Qiaquick gel extraction kit (Qiagen, Hilden, Germany). The gel extracted PCR products were cloned into pGEMT-Easy vector (Promega, Madison, Wisconsin, USA) and transformed into Escherichia coli $\mathrm{DH}_{5} \alpha$ cells. The recombinant clones were initially selected by blue-white colony screening and later confirmed by restriction enzyme digestion analysis using EcoR1 and BamH1. (Sambrook and Russell, 2001).

Genome sequence analysis. The confirmed recombinant clone was sequenced by availing a commercial sequencing facility (MWG Biotech, Bangalore, India). The partial genome sequence of the virus isolate obtained from Spathiphyllum spp., was initially BLAST [United States National Library of Medicine (NLM), Bethesda, MD, UDA] analysed using the NCBI public data base. Further sequence analysis was performed using the Molecular Evolutionary Genetics Analysis (MEGA) version 4.0 (Tamura et al., 2007). The sequence identity of the virus isolate studied herein was calculated with other aroid infecting potyviruses and a few other representative viruses of the genus Potyvirus at the coat protein $(\mathrm{CP})$ gene nucleotide, $\mathrm{CP}$ amino acid, and 3'-UTR levels.

The protease cleavage site at the $\mathrm{NIb} / \mathrm{CP}$ of the present virus isolate was determined by comparing the already established NIb/CP cleavage sites of other reported potyviruses (Adams et al., 2005a).

\section{Results and Discussion}

The total RNA isolated from Spathiphyllum spp., when subjected to RT-PCR using degenerate potyvirus primers yielded amplicons of $\sim 1.6 \mathrm{Kbp}$ (Fig. 1B). The amplicons corresponded to 3'-UTR, complete CP gene, and part of $\mathrm{NIb}$ gene. When the recombinant pGEMT-Easy vector having the insert was digested with EcoR1 and BamH1, 1.6 $\mathrm{kbp}$ insert released.

The generated sequence of the positive clone, when initially BLAST analyzed using NCBI public data base, revealed maximum identity with DsMV-M13 isolate reported from China. It showed maximum identity of $74.8 \%$ and $80.2 \%$ at CP gene nucleotide and amino acid levels, respectively with DsMV-M13 isolate. Where as at 3'-UTR (258 nt) nucleotide level, it had maximum identity of $62.5 \%$ with DsMV isolate from Vietnam (Table 1). Spathiphyllum spp., were found to be susceptible to DsMV 
Table 1. Per cent identity of CP gene and 3'-UTR of a potyvirus isolate associated with chlorotic vein banding symptoms on Spathiphyllum spp., in Andhra Pradesh, India with other potyviruses*

\begin{tabular}{|c|c|c|c|c|}
\hline Virus & $\begin{array}{c}\text { GenBank } \\
\text { accession } \\
\text { numbers }\end{array}$ & $\begin{array}{l}\% \text { CP gene } \\
\text { nucleotide a } \\
\text { identity }\end{array}$ & $\begin{array}{c}\% \mathrm{CP} \\
\text { aminoacid } \\
\text { identity }\end{array}$ & $\begin{array}{c}\% 3^{\prime}- \\
\text { UTR } \\
\text { identity }\end{array}$ \\
\hline $\begin{array}{l}\text { Spathiphyllum chlo- } \\
\text { rotic vein banding } \\
\text { virus }\end{array}$ & GQ421462 & 100 & 100 & 100 \\
\hline DsMV-Kerala & FJ160764 & 71.9 & 78.5 & 59.6 \\
\hline DsMV-Florida & (U00122) & 70.1 & 74.1 & 61.0 \\
\hline DsMV-Florida & U08124 & 72.7 & 78.5 & 60.6 \\
\hline DsMV-M13 & NC003537 & 74.8 & 79.9 & 60.2 \\
\hline DsMV-Vietnam & DQ925466 & 68.3 & 74.6 & 62.5 \\
\hline DsMV-Vn/CE2 & DQ925465 & 73.4 & 79.2 & 61.3 \\
\hline DsMV-Vn/CE1 & DQ925464 & 71.4 & 71.4 & 61.0 \\
\hline DsMV-TW & AJ298036 & 74.3 & 80.1 & 60.0 \\
\hline BCMV-NL & EU713858 & 58.1 & 65.4 & 32.0 \\
\hline SMV & S42280 & 57.9 & 64.2 & 39.0 \\
\hline WMV-2 & D13913 & 57.8 & 63.3 & 40.0 \\
\hline ZaMMV & AY626825 & 54.8 & 54.9 & 37.5 \\
\hline $\begin{array}{l}\text { PeLMV-Haiphong, } \\
\text { (Vietnam) }\end{array}$ & DQ851494 & 53.6 & 53.0 & 30.3 \\
\hline KoMV-Cal-India & EU924640 & 48.8 & 48.6 & 17.3 \\
\hline KoMV-Col-India & EU979524 & 48.6 & 48.6 & 15.1 \\
\hline KoMV-Dief-India & EU924639 & 48.8 & 48.6 & 17.3 \\
\hline KoMV-S.Korea & AB081519 & 48.4 & 48.6 & 15.1 \\
\hline
\end{tabular}

*BCMV: Bean common mosaic virus, DsMV: Dasheen mosaic virus, KoMV: Konjac mosaic virus, PeLMV: Peace lily mosaic virus, SMV: Soybean mosaic virus, WMV-2: Watermelon mosaic virus-2, ZaMMV: Zantedeschia mild mosaic virus.

and PeLMV infections (Zettler et al., 1978 and GenBank A/ C DQ851494). In India, DsMV was reported to infect four aroid ornamental (Aglaonema spp., Philodendron spp., Colocasia esculenta and Zantedeschia spp.) plants (Ram et al., 2003). The present virus isolate shared identity of $71.9 \%$ (CP gene nucleotide), $78.2 \%$ (CP amino acid), and $59.6 \%$ (3'-UTR) with recently reported DsMV-elephant foot yam isolate from Kerala state, India (Table 1). The deduced size of CP gene of this isolate is 906 nucleotides in length encoding 302 amino acids with a molecular weight of $33.57 \mathrm{kDa}$. The CP amino acid based phylogenetic analysis revealed that the virus isolate from Spathiphyllum spp., clustered along with DsMV isolates but as a distinct branch (Fig. 2). Like several other aphid transmitted potyviruses, the $\mathrm{CP}$ of this virus also contained DAG triplet in its amino terminus. The $\mathrm{NIb} / \mathrm{CP}$ cleavage site identified is $\mathrm{Q} / \mathrm{A}$.

According to the molecular criteria suggested by Adams et al. (2005b), different potyvirus species within the genus have $\mathrm{CP}$ gene nucleotide percent identity between 35.6 to

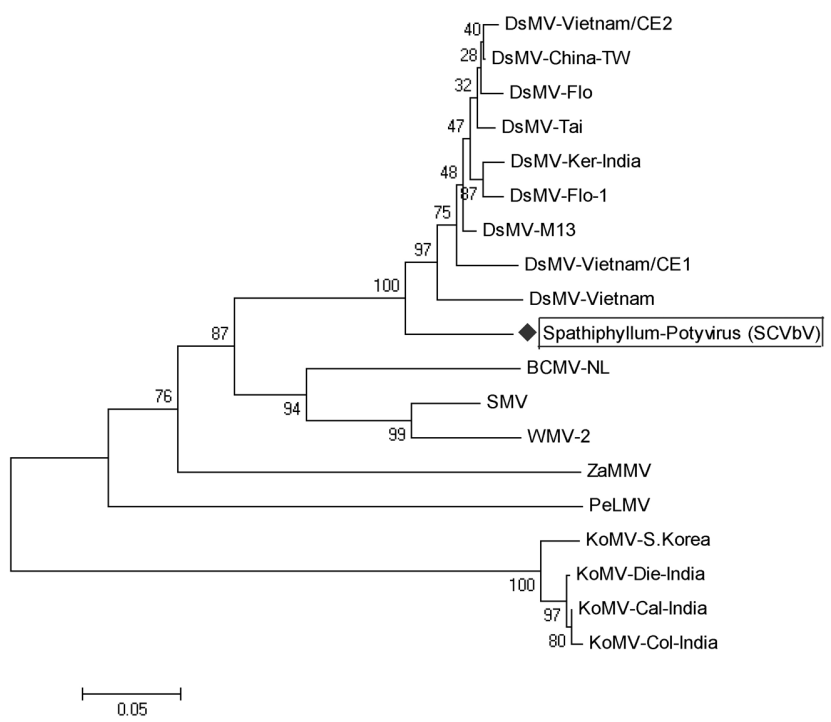

Fig. 2. Spathiphyllum chlorotic vein banding virus isolate (SCVbV) CP amino acid based phylogenetic tree showing the relationships with other potyviruses of the genus Potyvirus. The virus acronyms and GenBank A/C numbers are given in Table 1 . The phylogenetic tree was constructed using MEGA 4.0. The values at the forks indicate the number of trees that this grouping occurred after bootstrapping the data. The scale bar shows the number of substitutions per base.

81.1, CP amino acid percent identity between 13.2 to 88.6 , and 3'-UTR nucleotide percent identity between 30.9 to 84 . Based on these criteria, the potyvirus isolate associated with prominent chlorotic vein banding symptoms on Spathiphyllum spp., in Andhra Pradesh, India was identified as a distinct virus species in the genus Potyvirus, and authors proposed the name Spathiphyllum chlorotic vein banding virus $(\mathrm{SCVbV})$. Further work on biological properties of the virus and its full length genome sequence analysis may substantiate its exact identity within the genus Potyvirus.

\section{Acknowledgements}

The authors are thankful to the Department of Biotechnology (DBT), Ministry of Science and Technology, Government of India, New Delhi for financial assistance.

\section{References}

Adams, M. J., Antoniw, J. F. and Beaudoin, F. 2005a. Overview and analysis of the polyprotein cleavage sites in the family Potyviridae. Mol. Plant Pathol. 6:471-487.

Adams, M. J., Antoniw, J. F. and Fauquet, C. 2005b. Molecular criteria for genus and species discrimination within the family Potyviridae. Arch. Virol. 150:459-479.

Ahlawat, Y. S., Pant, R. P. and Bhagawati, K. N. 2003. Association of carla- and poty-viruses with mosaic disease of elephant 
foot yam. Indian Phytopath. 56:300-301.

Clark, M. F. and Bar-Joseph, M. 1984. Enzyme immunoassays in plant virology. In Maramorosch, K. and Koprowski, H. (Eds.), Methods Virol. 51-58. New York: Academic Press, USA

Chen, C. C., Chao, C. H., Chen, C. C., Yeh, S. D., Tsai, H. T. and Chang, C. A. 2003. Identification of Turnip mosaic virus isolates causing yellow stripe and spot on calla lily. Plant Dis. 87:901-905.

Chen, C. C., Hsu, H. T., Cheng, Y. H., Huang, C. H., Liao, J. Y., Tsai, H. T. and Chang, C. A. 2006. Molecular and serological characterization of a distict potyvirus causing latent infection in calla lilies. Bot. Studies 47:369-378.

Farcryrol, K., Pearson, M. N., Grisoni, M., Cohen, D. and Beck, D. 2006. Vanilla mosaic virus isolates from French Polynesia and the Cook Islands are Dasheen mosaic virus strains that exclusively infect vanilla. Archi. Virol. 151:905-919.

Gibbs, A. and Mackenzie, A. 1997. A primer pair for amplifying part of the genome of all potyvirids by RT-PCR. J. Virol. Methods 63:9-16.

Huang, C. H. and Chang, Y. C. 2005. Identification and molecular characterization of Zantedeschia mild mosaic virus, a new calla lily-infecting potyvirus. Archi. Virol. 150:1221-1230.

Kwon, S. B., Ha, J. H., Yoon, J. Y. and Ryu, K. H. 2002. Zantedeschia mosaic virus causing leaf mosaic symptom in calla lily is a new potyvirus. Archi. Virol. 147:2281-2289.

Nishiguchi, M., Yamasaki, S., Lu, X. Z., Shimoyama, A., Hanada, K., Sonoda, S., Shimon, M., Sakai, J., Mikoshiba, Y. and Fujisawa, I. 2006. Konjak mosaic virus: the complete nucleotide sequences of the genomic RNA and its comparision with other potyviruses. Archi. Virol. 151:1643-1650.

Padmavathi, M., Srinivas, K. P., Subba Reddy, Ch. V., Ramesh, B., Navodayam, K., Krishnaprasadji, J., Babu Ratan, P. and Sreenivasulu, P. 2010. Konjac mosaic virus associated with mosaic diseases of three aroid plant species in Andhra Pradesh, India. J. Phytopath. (DOI: 10.1111/j.1439-0434. 2010.01720.X).

Pandit, M. K., Nath, P. S., Mukhopadhyay, S., Devonshire, B. J. and Jones, P. 2001. First report of Dasheen mosaic virus in elephant foot yam in India. Plant Pathol. 50:802.

Pham, K., Langveldt, S. A., Lemmers, M. E. C. and Derks, A. F. L. M. 2002. Detection and identification of potyviruses in Zantedeschia. Acta Hort. 568:143-148.

Ram, R., Joshi, A., Verma, N., Kulshrestha, S., Raikhy, G, Hallan, V. and Zaidi, A. A. 2003. First report of Dasheen mosaic virus infecting four ornamental aroids in India. Plant Pathol. 52:411.

Sambrook, J. and Russel, D. W. 2001. Molecular Cloning, a laboratory manual, Vol I, II and III, Cold Spring Harbor Laboratory, New York, USA.

Shi, Y. H., Hong, X. Y., Chen, J., Adams, M. J., Zheng, H. Y., Lin, L., Qin, B. X. and Chen, J. P. 2005. Further molecular characterization of potyviruses infecting aroid plants for medicinal use in China. Arch. Virol. 150:25-135.

Tamura, K., Dudley, J., Nei, M. and Kumar, S. 2007. MEGA4: Molecular Evolutionary Genetics Analysis (MEGA) software version 4.0. Mol. Biol. Evo. 24:1596-1599.

Zettler, F. W., Abo El-Nil, M. M. and Hiebert, E. 1978. Dasheen mosaic virus. CMI/AAB Descriptions of Plant Viruses No.191. 